\title{
An Experimental Investigation of Strain Rate, Temperature and Humidity Effects on the Mechanical Behavior of a Perfluorosulfonic Acid Membrane
}

\author{
Zongwen Lu \\ University of Delaware \\ Melissa Lugo \\ University of Delaware \\ Michael H. Santare

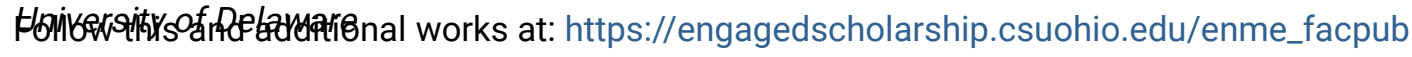 \\ eqtaetidf. HKarlisscrianical Engineering Commons

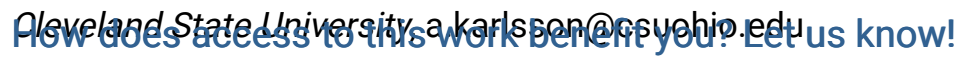

P.ebliskiseris Statement

$\forall$ Q

Power Sources. Changes resulting from the publishing process, such as peer review, editing, corrections, structural formatting, and other quality control mechanisms may not be reflected in

See next page for additional authors
this document. Changes may have been made to this work since it was submitted for publication. A definitive version was subsequently published in Journal of Power Sources, 214, , (09-15-2012); 10.1016/j.jpowsour.2012.04.094

\section{Original Citation}

Lu, Z., Lugo, M., Santare, M. H., 2012, "An Experimental Investigation of Strain Rate, Temperature and Humidity Effects on the Mechanical Behavior of a Perfluorosulfonic Acid Membrane," Journal of Power Sources, 214pp. 130-136.

This Article is brought to you for free and open access by the Mechanical Engineering Department at EngagedScholarship@CSU. It has been accepted for inclusion in Mechanical Engineering Faculty Publications by an authorized administrator of EngagedScholarship@CSU. For more information, please contact library.es@csuohio.edu. 


\section{Authors}

Zongwen Lu, Melissa Lugo, Michael H. Santare, Anette M. Karlsson, F. Colin Busby, and Peter Walsh 


\title{
An experimental investigation of strain rate, temperature and humidity effects on the mechanical behavior of a perfluorosulfonic acid membrane
}

\author{
Zongwen Lu ${ }^{a}$, Melissa Lugo ${ }^{a}$, Michael H. Santare ${ }^{\mathrm{a}, *}$, Anette M. Karlsson ${ }^{\mathrm{a}}$, F. Colin Busby ${ }^{\mathrm{b}}$, Peter Walsh ${ }^{\mathrm{b}}$ \\ a Department of Mechanical Engineering, University of Delaware, Newark, DE 19716, USA \\ ${ }^{\mathrm{b}}$ Gore Fuel Cell Technologies, Elkton, MD 21922, USA
}

\section{Introduction}

Durability of the membranes during long-term fuel cell operation is a major obstacle to widespread commercialization of proton exchange membrane fuel cells (PEMFCs). The PEMs are prone to failure in the form of chemical degradation and mechanical damage [1-6]. Studies have shown that the mechanical stresses in the membrane, induced by hygro-thermal changes in the fuel cell, are primarily responsible for the mechanical damage [7-12]. Therefore, characterizing the hygro-thermo-mechanical properties of the membrane is an important step toward understanding the failure and providing the science base for increasing the durability of PEM fuel cells.

\footnotetext{
* Corresponding author. Tel.: +1 302831 2421; fax: +1 3028313619

E-mail address: santare@udel.edu (M.H. Santare).
}

Our previous experimental work showed that Young's modulus and the proportional limit stress of a PFSA membrane (Nafion ${ }^{\circledR} 112$ membrane ${ }^{1}$ ) both decrease as humidity and temperature increase [13]. These studies also showed that higher temperature leads to lower break stress and higher break strain while humidity has little effect on the break stress and break strain [13]. However, in the previous work, all the loadings were done at $0.2 \mathrm{~mm} / \mathrm{mm}$ per minute (in the following, the notation $0.2 \mathrm{~min}^{-1}$ will be used for simplicity) and the tests did not take into account the timedependent nature of the membrane behavior.

Limited work concerning testing and modeling of the timedependent mechanical behavior of Nafion ${ }^{B}$ membranes is available in the literature [14-17]. However, the time-dependent mechanical properties of Nafion ${ }^{\otimes}$ membranes warrant further

\footnotetext{
1 Nafion is a registered trademark of E.I. DuPont De Nemours \& Co.
} 
study, particularly over a broad range of strain rates, temperatures and humidities.

As an extension of our previous work, this work investigates the time-dependent mechanical behavior of a PFSA membrane (Nafion ${ }^{\circledR} 211$ membrane) at selected strain rates for a range of temperatures and humidities on a MTS Alliance ${ }^{\mathrm{TM}} \mathrm{RT} / 5$ material testing system fitted with either a custom-designed environmental chamber or a temperature-controlled water tank. ${ }^{2}$

PFSA membranes typically swell with exposure to humid air or water due to their hydrophilic nature. Our previous numerical simulations have shown that swelling is the predominant driving force in the development of mechanical stresses in the PEM during fuel cell operation [18]. However, since the tensile and relaxation tests were conducted in an environmental chamber, it is difficult to continuously measure the dimensions of the specimen at the time of testing. Moreover, knowing the instantaneous cross-sectional area of the membrane is necessary in order to determine the true stress-true strain response of a swollen membrane. Therefore, in this work we conducted a separate set of experiments to independently characterize the swelling behavior of the membrane as a function of temperature and humidity.

From the results generated in this study, we also developed a viscoelastic-plastic numerical model to analyze the experimental results and simulate membrane behavior in-situ, which is discussed in a companion paper [19]. In the following, we first discuss the experimental procedure, and then discuss the results.

\section{Experimental procedure}

We measured the tensile mechanical response of Nafion ${ }^{\circledR} 211$ membrane at three strain rates $\left(5 \mathrm{~min}^{-1}, 0.2 \mathrm{~min}^{-1}\right.$, and quasistatic $)^{3}$ for 20 temperature and humidity combinations, i.e. four selected temperatures $\left(25^{\circ} \mathrm{C}, 45^{\circ} \mathrm{C}, 65^{\circ} \mathrm{C}\right.$, and $\left.80^{\circ} \mathrm{C}\right)$ and five selected relative humidities (30\%, 50\%, 70\%, 90\%, and liquid water).

The tests were conducted using an MTS Alliance ${ }^{\mathrm{TM}} \mathrm{RT} / 5$ material testing system fitted with either an ESPEC custom-designed environmental chamber, or a temperature-controlled water tank (Fig. 1a and b). The environmental chamber was used to set the desired temperature and relative humidity for testing and the water tank to investigate the material behavior in liquid water at selected temperatures. We conducted two sets of experiments at each environmental condition: tensile tests and relaxation tests. As shown in Fig. 2, tensile tests at two selected strain rates $\left(5 \mathrm{~min}^{-1}\right.$ and $0.2 \mathrm{~min}^{-1}$ ) and relaxation tests at three selected holding strains $(0.05,0.1$ and 0.2$)$ were investigated.

We tested three specimens at each temperature, humidity and tensile loading rate or relaxation holding strain combination. For each specimen, the pretest thickness and width were measured with a micrometer and a caliper, respectively, at three locations along the sample before testing. The averages of these three measurements were used as the nominal dimensions of the sample under ambient conditions. The $20 \mathrm{~mm}$ wide specimen was aligned with the extension rod and clamped into a pair of vise-action grips to provide a nominal gauge length of $50 \mathrm{~mm}$ as determined by the grip separation. The $20 \mathrm{~mm}$ width is larger than used in our previous studies in order to maintain a reasonable signal-to-noise ratio in the load cell at low stresses.

\footnotetext{
2 Because the Nafion ${ }^{\circledR} 112$ membrane is no longer being produced, the material in the present study is Nafion ${ }^{\circledR} 211$ membrane. The primary difference is that in the Nafion ${ }^{\circledR} 211$ membrane the ionomer is cast while in the Nafion ${ }^{\circledR} 112$ membrane it is extruded.

3 We also conducted a limited set of tensile tests at a higher strain rate $\left(12 \mathrm{~min}^{-1}\right)$ and found very similar stress-strain response to the response seen at the strain rate of $5 \mathrm{~min}^{-1}$.
}
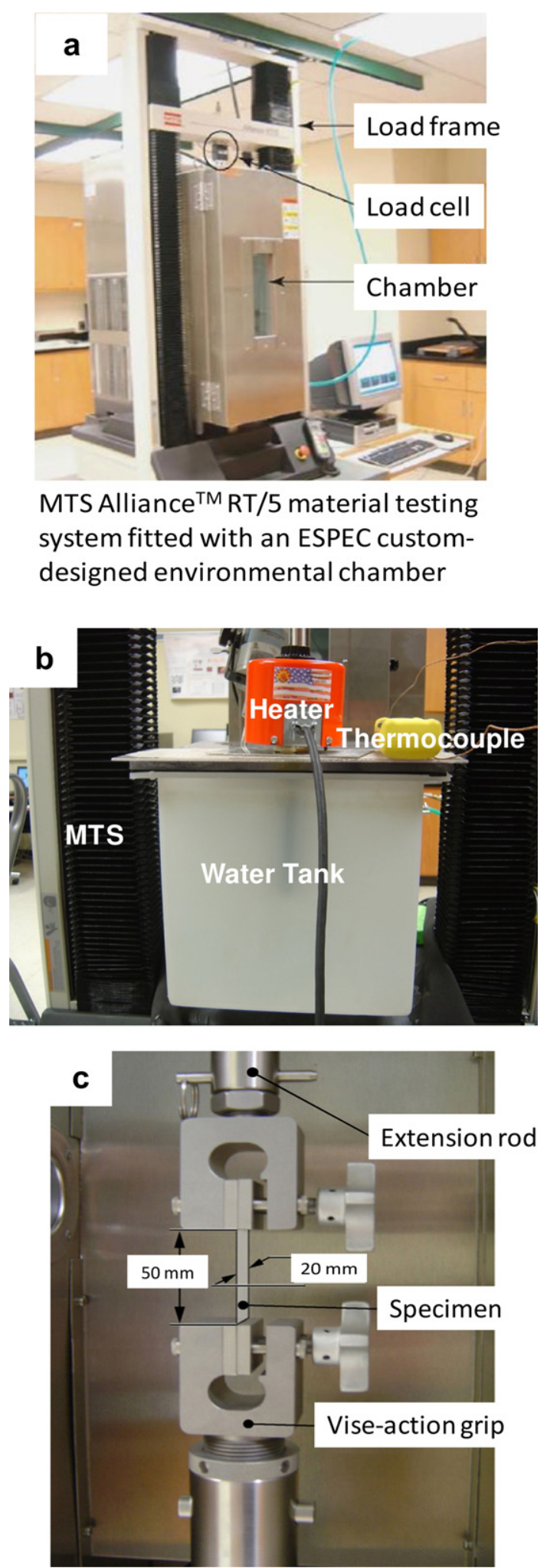

Fig. 1. Experimental equipment MTS Alliance ${ }^{\mathrm{TM}} \mathrm{RT} / 5$ material testing system fitted with (a) an ESPEC custom-designed environmental chamber [13]; (b) a temperaturecontrolled water tank; and (c) experimental setup [20].

To achieve the desired environmental conditions in the chamber, the temperature was first set to the desired value and allowed to stabilize, and then the humidity was slowly increased (or decreased) to the desired RH value with the specimen slack. 


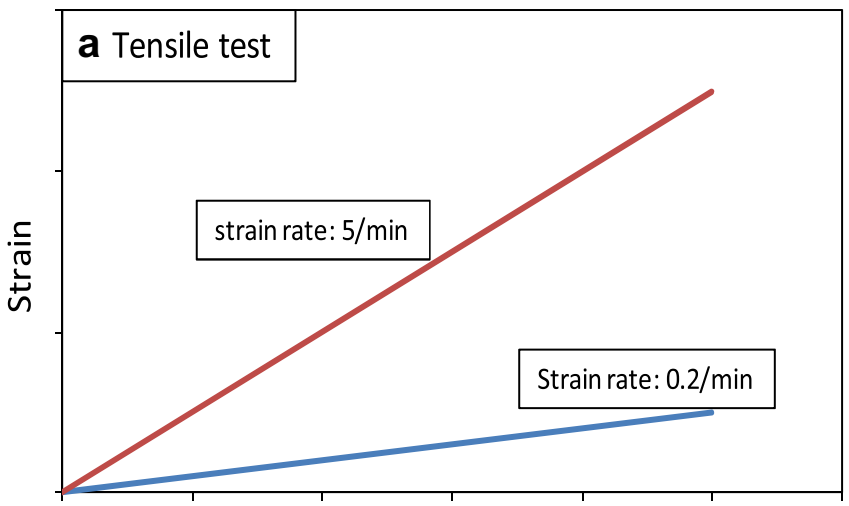

Time

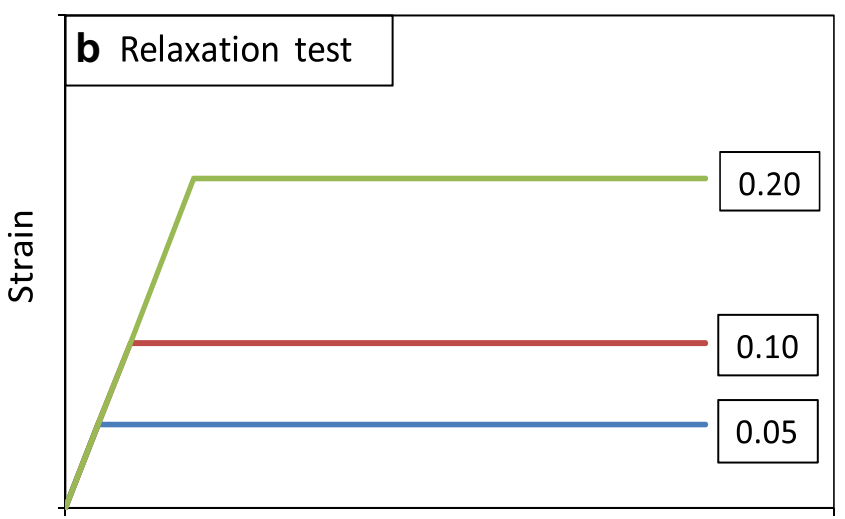

Time

Fig. 2. Schematic representations of the experiments conducted: (a) tensile tests at two selected strain rates; and (b) relaxation tests at three selected holding strains.

Both the temperature and humidity were kept at the desired values for at least half an hour before applying tension to ensure equilibrated swelling. During this process, the length of the specimen changes due to the thermal and swelling deformations of the membrane. Before applying a force, the crosshead was manually adjusted until the initial force applied to the specimen was brought to a small, finite tensile force ( $\sim 0.01$ Newton), eliminating the initial slack caused by thermal and swelling expansions. For calculating the strain, we took the reference length of the specimen as the original length at ambient conditions, plus the total displacement of the crosshead corresponding to the change in length caused by the change in environmental conditions.

To characterize the material under fully saturated conditions, we conducted "liquid water tests", where the specimen was submerged in a temperature-controlled water tank (Fig. 1b). To achieve the desired temperature, an electric heater and stirrer were used to increase the water temperature and to make it uniform in the water tank. We measured the temperature using a thermocouple and allowed the temperature to stabilize at the desired value for no less than half an hour. We then conducted the tests in a same manner as the tests conducted in the environmental chamber. Note that the buoyancy effect on the upper grip and extension rod before testing was eliminated by zeroing the load cell force while the specimen, grip and extension rod were submerged in the water. As the specimen was pulled, the change in the buoyancy due to the lifting of the extension rod was calculated to be less than $2 \%$ of the force needed to deform the specimen and was therefore neglected.

Using the procedure and equipment described above, we conducted a separate set of experiments to measure the steady state swelling at four temperatures $\left(25^{\circ} \mathrm{C}, 45^{\circ} \mathrm{C}, 65^{\circ} \mathrm{C}\right.$, and $\left.80^{\circ} \mathrm{C}\right)$ and five relative humidities (30\%, 50\%, 70\%, 90\%, and liquid water). We designed two temperature/humidity cycles (Fig. 3) to determine the swelling in the in-plane direction (length direction). The two cycles were explored to investigate if the material swelling has hygro-thermal history dependence. One test sample with gauge length of $50 \mathrm{~mm}$ and nominal width of $20 \mathrm{~mm}$ was used throughout each cycle, and only steady state swelling was considered.

Since we use the results of the swelling measurements to determine the true stress and true strain in the tensile and relaxation tests, the swelling results are discussed first in the following.

\section{Experimental results}

\subsection{Swelling behavior}

Fig. 4 shows the in-plane dimensional changes of Nafion ${ }^{\circledR} 211$ membrane for the two cycles shown in Fig. 3. The results show very good agreement between the two cycles, indicating that the load (temperature and humidity) history effect is small for the cases investigated.

Fig. 5 shows the average swelling of the Nafion ${ }^{\circledR} 211$ membrane for the complete range of temperature and humidity combinations considered. The swelling properties in liquid water were measured in the temperature-controlled water tank. Figs. 4 and 5 show that the membrane swells as the temperature or humidity increases. Moreover, the dimensional change is nearly proportional to the increase of humidity from $30 \%$ to $90 \%$, indicating that the swelling coefficient is almost constant. However, when moving from humid air into liquid water, the linear trend is not followed any more, and a significantly larger swelling coefficient is observed (Fig. 5). Some
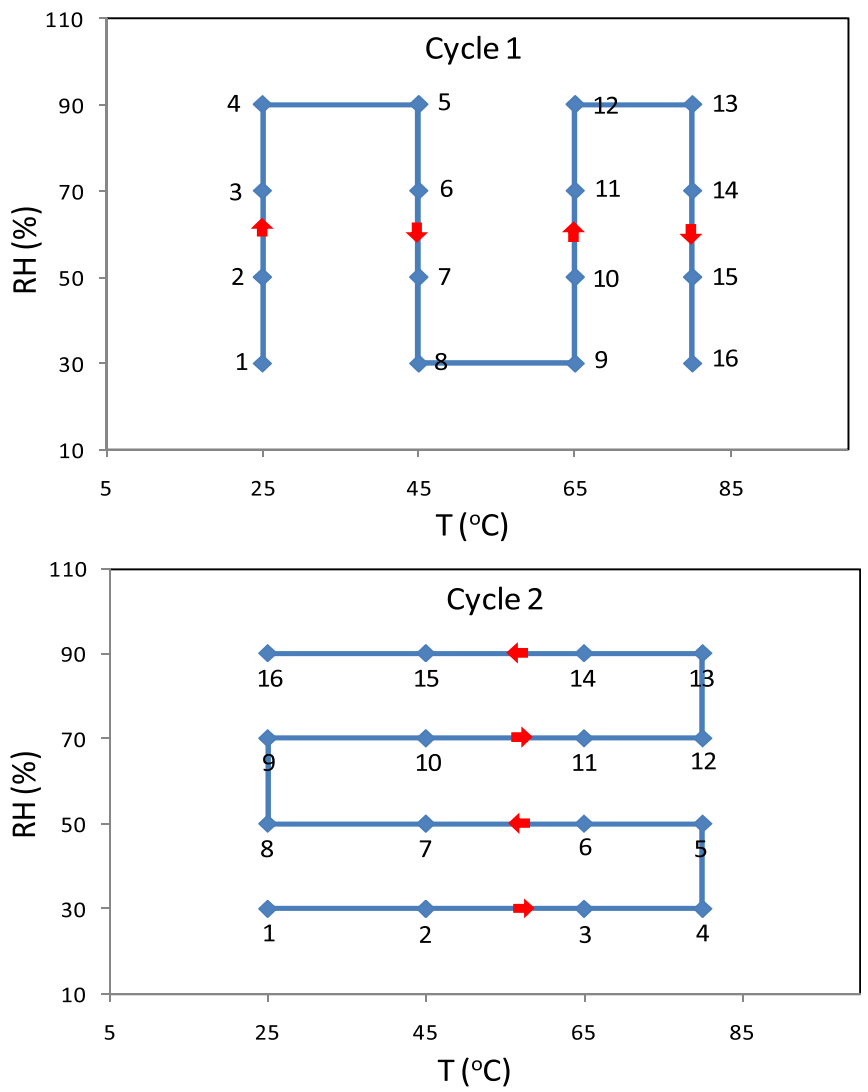

Fig. 3. Two temperature/humidity cycles showing the sequence of 16 measurements used to determine the in-plane swelling properties of Nafion ${ }^{\circledR} 211$ membrane. 


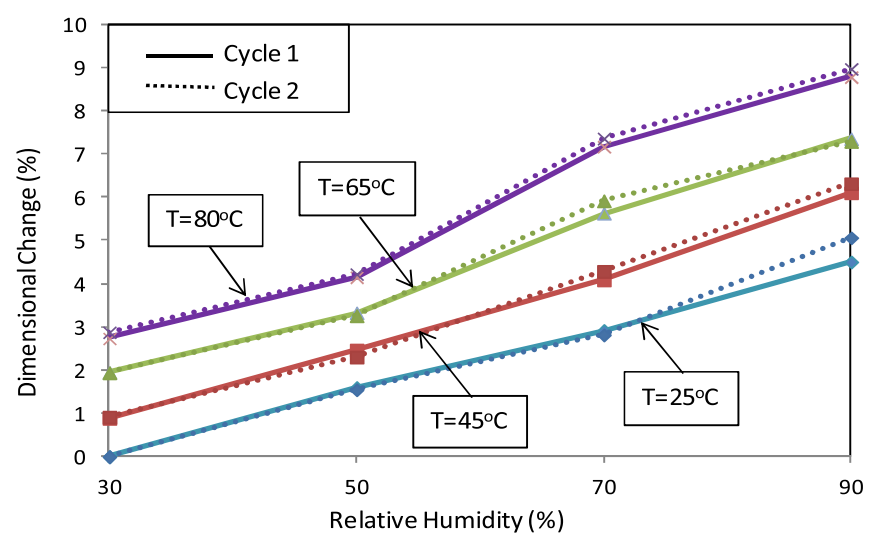

Fig. 4. In-plane swelling of Nafion ${ }^{\circledR} 211$ membrane for the two temperature/humidity cycles shown in Fig. 3.

researchers have suggested that the absorption mechanism is different between saturated water vapor (100\% relative humidity) and liquid water at the same temperature, e.g. Schroeder's paradox [21].

These measured in-plane dimensional changes along with an assumption of swelling isotropy, which is supported by our previous work [13, 22], are used to calculate the true stress and true strain values in the following results.

\subsection{Stress-strain response}

Fig. 6 shows typical true stress-true strain curves for Nafion ${ }^{\circledR}$ 211 membranes at $45{ }^{\circ} \mathrm{C}$ and $50 \%$ relative humidity for several strain rates (Quasi-static, $0.2 \mathrm{~min}^{-1}$, and $5 \mathrm{~min}^{-1}$ ). True stress and true strain relationships are used to take into account large deformation. True stress and true strain can be related to engineering stress and engineering strain according to

$\sigma_{\text {true }}=\left(1+\varepsilon_{\mathrm{e}}\right) \sigma_{\mathrm{e}}$
$\varepsilon_{\text {true }}=\ln \left(1+\varepsilon_{\mathrm{e}}\right)$

The figure shows that the stiffness increases as the strain rate increases. The results for the zero strain rate condition (quasistatic) are derived from the three equilibrium stress-holding strain points obtained from relaxation tests (Fig. 7) as described below.

Fig. 7 shows that when the sample is held at constant strain $(0.05,0.1,0.2)$, the stress decreases quickly during the first few

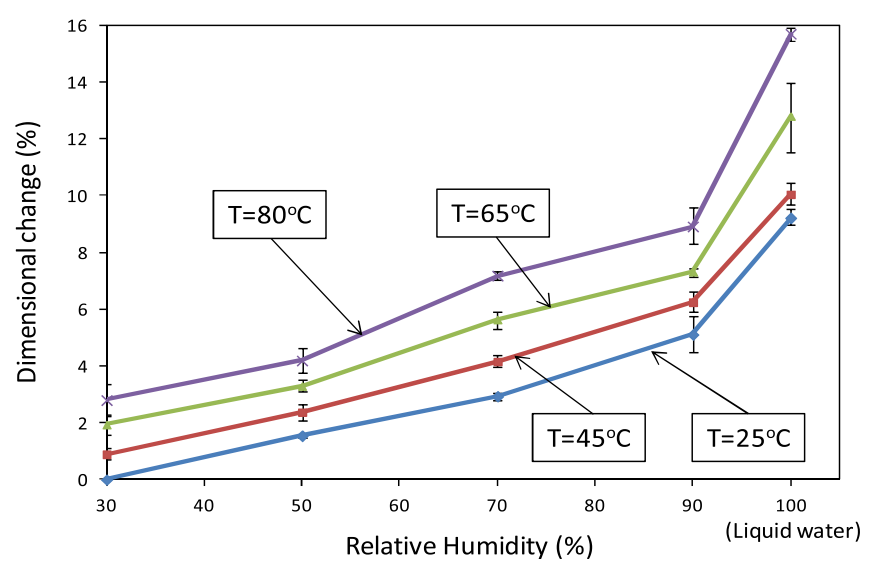

Fig. 5. In-plane swelling of Nafion ${ }^{\circledR} 211$ membrane as a function of temperature and humidity.

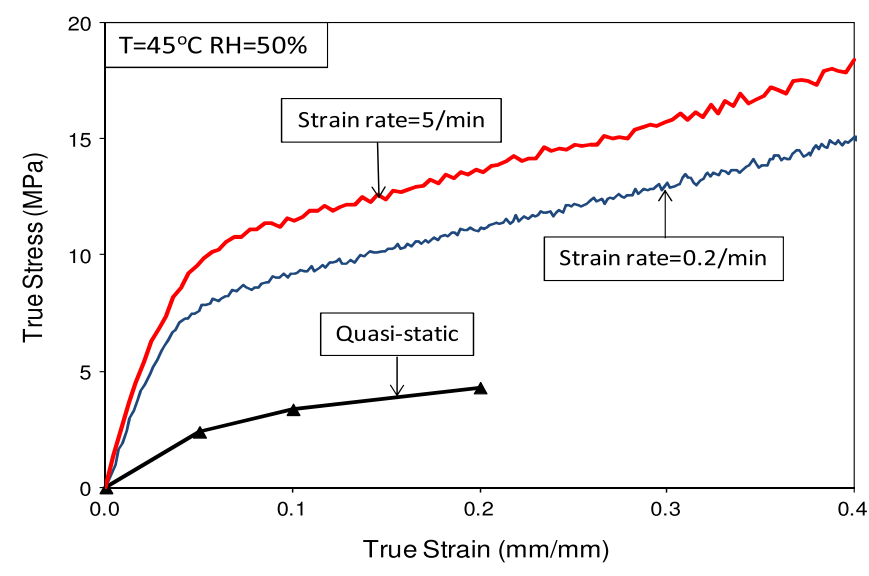

Fig. 6. True stress-true strain curves at selected strain rates for $T=45^{\circ} \mathrm{C}, \mathrm{RH}=50 \%$ (the quasi-static results are derived).

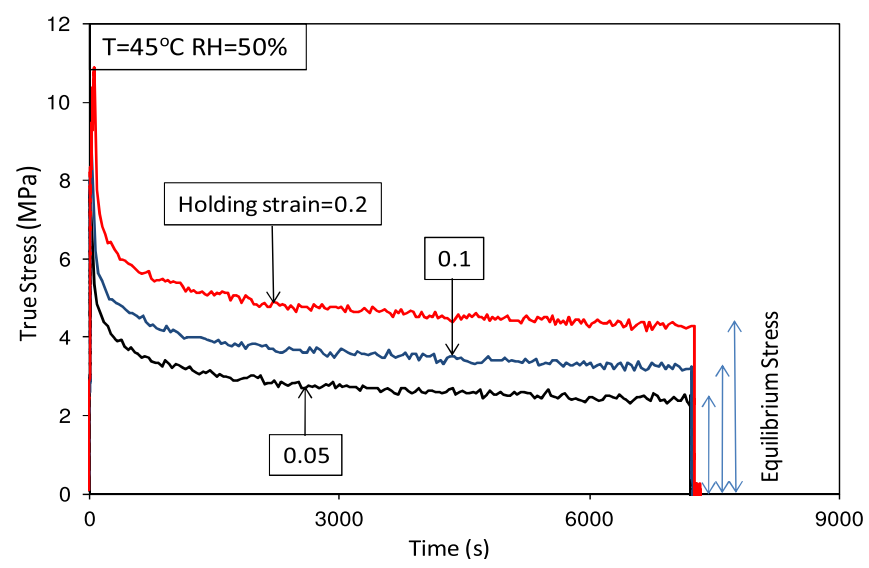

Fig. 7. True stress-time curves for relaxation tests at selected holding strains for $T=45^{\circ} \mathrm{C}, \mathrm{RH}=50 \%$.

minutes, and the rate of decrease gradually slows until it is changing very slowly after $2 \mathrm{~h}$. In an actual relaxation test, the sample is held at this constant strain until the stress reaches an equilibrium value. However, due to limitations in the testing equipment and practical considerations in the current study, we ran the relaxation tests for $2 \mathrm{~h}$ and assumed that the stress level at

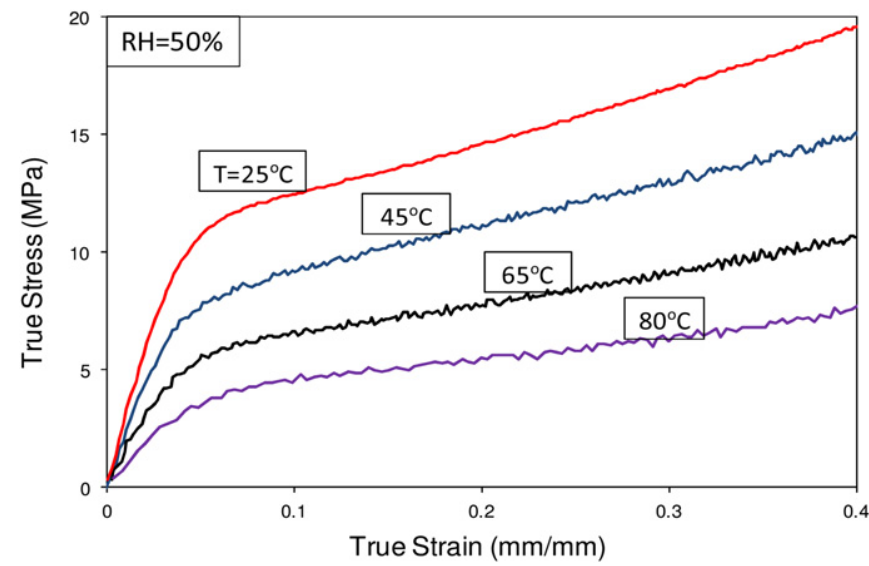

Fig. 8. True stress-true strain curves for tensile tests at a strain rate of $0.2 \mathrm{~min}^{-1}$ with $\mathrm{RH}=50 \%$ and selected temperatures. 


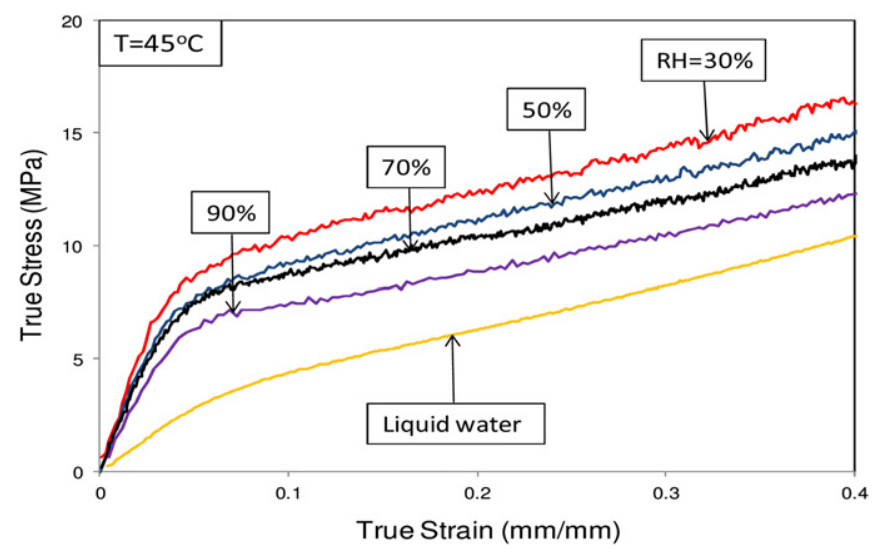

Fig. 9. True stress-true strain curves for tensile tests at a strain rate of $0.2 \mathrm{~min}^{-1}$ with $T=45^{\circ} \mathrm{C}$ and different relative humidities.

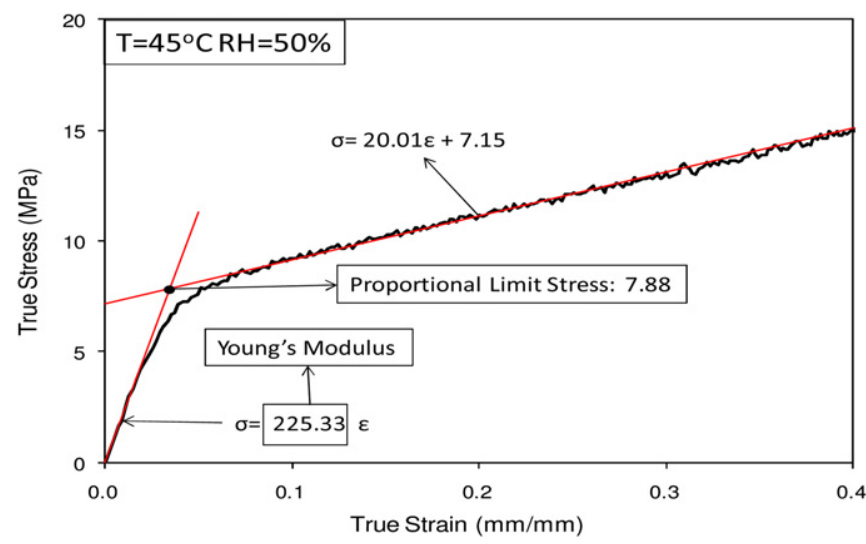

Fig. 10. Graphical definition of proportional limit stress and Young's modulus [13]

that time was the equilibrium stress. By assuming that the zero strain condition corresponds to a stress free state, we fitted a curve through zero and the three equilibrium stresses determined from the relaxation tests to get an approximation to the quasi-static stress-strain curve for tensile tests as shown in Fig. 6.

Fig. 8 shows typical true stress-true strain curves for Nafion ${ }^{\circledR}$ 211 membranes loaded with a strain rate of $0.2 \mathrm{~min}^{-1}$ at $50 \%$ relative humidity and a range of temperatures. The figure shows

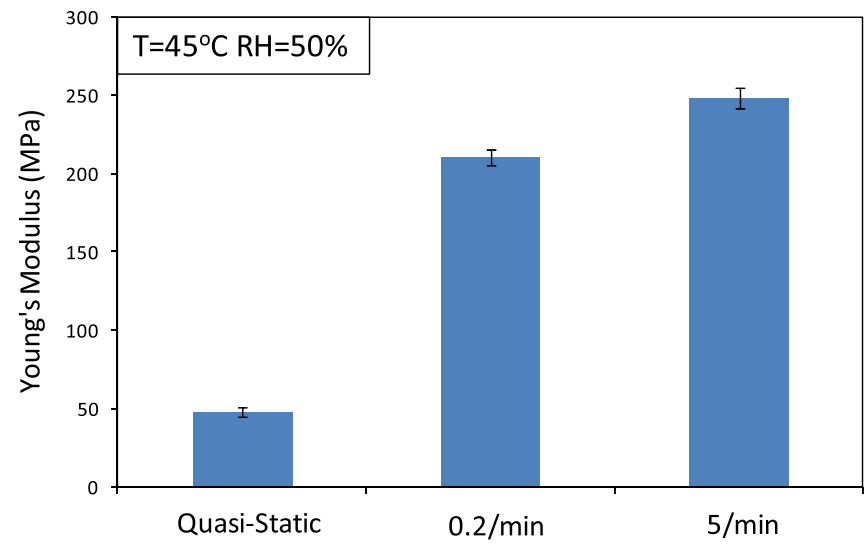

Fig. 11. Young's modulus of Nafion ${ }^{\circledR} 211$ membranes as a function of strain rate at $T=45^{\circ} \mathrm{C}, \mathrm{RH}=50 \%$.
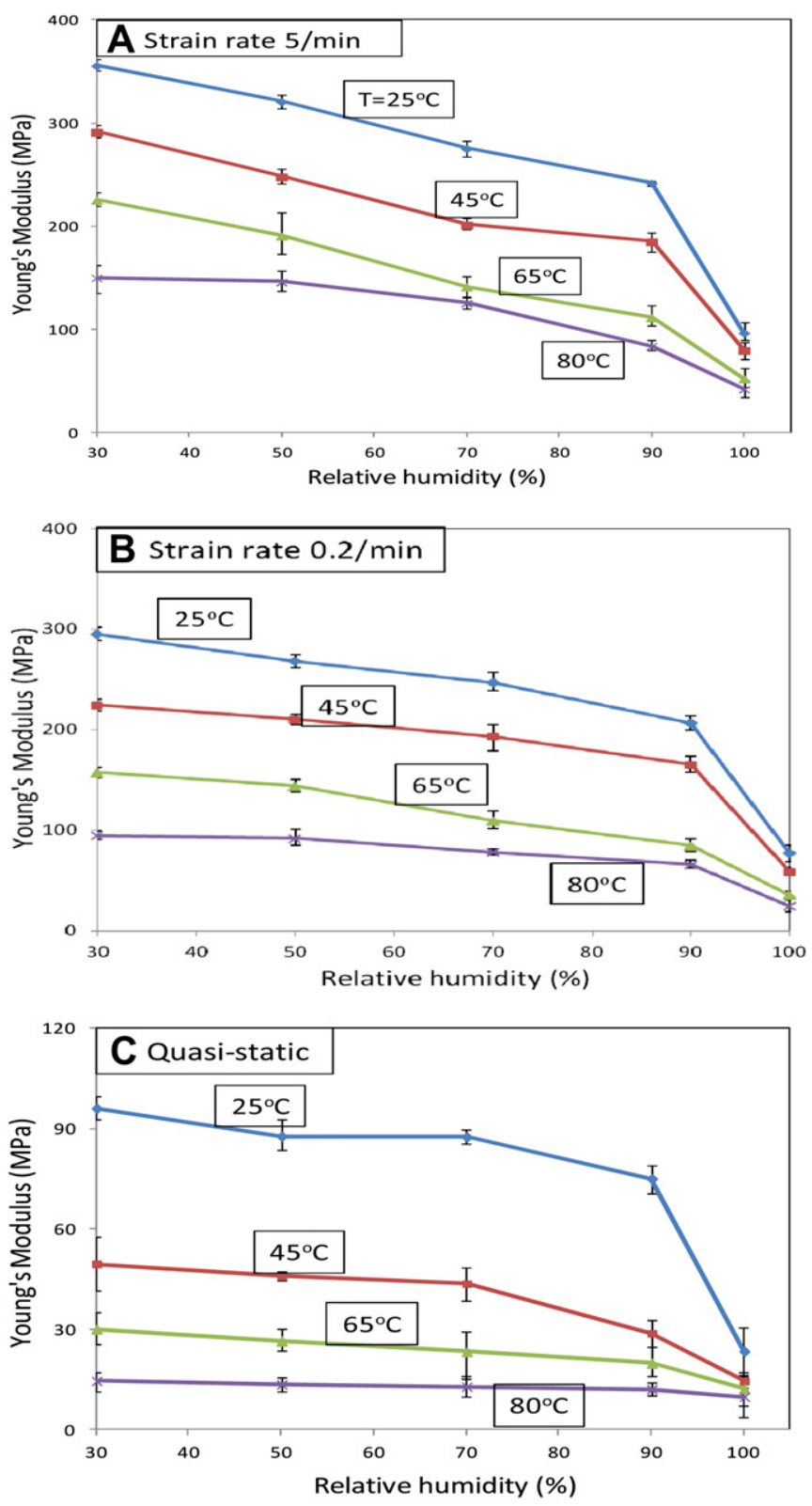

Fig. 12. Young's modulus of Nafion ${ }^{\circledR} 211$ membranes as a function of relative humidity at various temperatures with a strain rate of (a) $5 \mathrm{~min}^{-1}$; (b) $0.2 \mathrm{~min}^{-1}$; and (c) quasi-static.

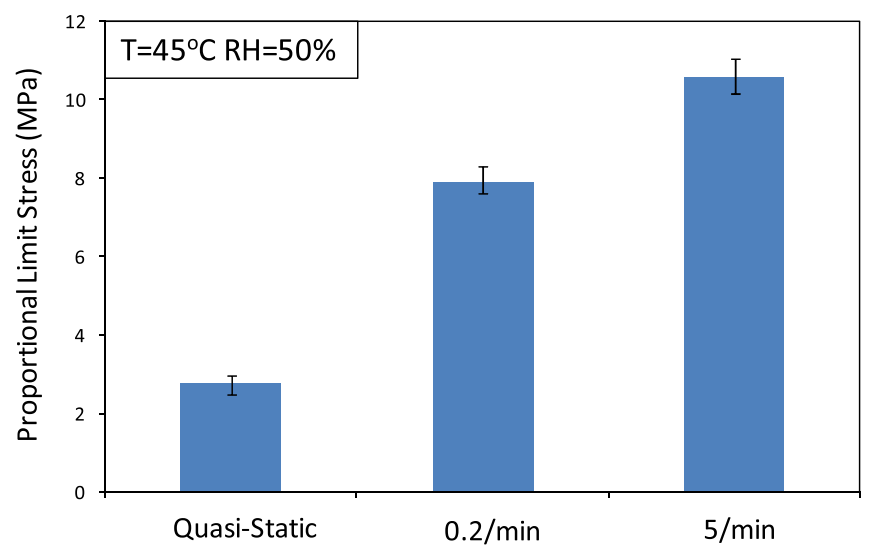

Fig. 13. Proportional limit stress of Nafion ${ }^{\circledR} 211$ membranes as a function of strain rate at $T=45^{\circ} \mathrm{C}, \mathrm{RH}=50 \%$. 
that the tensile stiffness decreases with increasing temperature for a fixed relative humidity.

Similarly, Fig. 9 shows that the tensile stiffness decreases with increasing relative humidity at a fixed temperature. Figs. 6, 8 and 9 also show that, in the range of values studied, the mechanical response of the Nafion ${ }^{\circledR} 211$ membrane is more sensitive to changes in strain rate or temperature than to changes in humidity.

\subsection{Characteristic mechanical properties}

The initial slope of the tensile true stress-true strain response is taken as Young's modulus for the material. However, based on the monotonically increasing load used in the tests (Figs. 6-9), it is not possible to identify the onset of yielding or a yield limit. Instead, we report the proportional limit stress, which we have defined
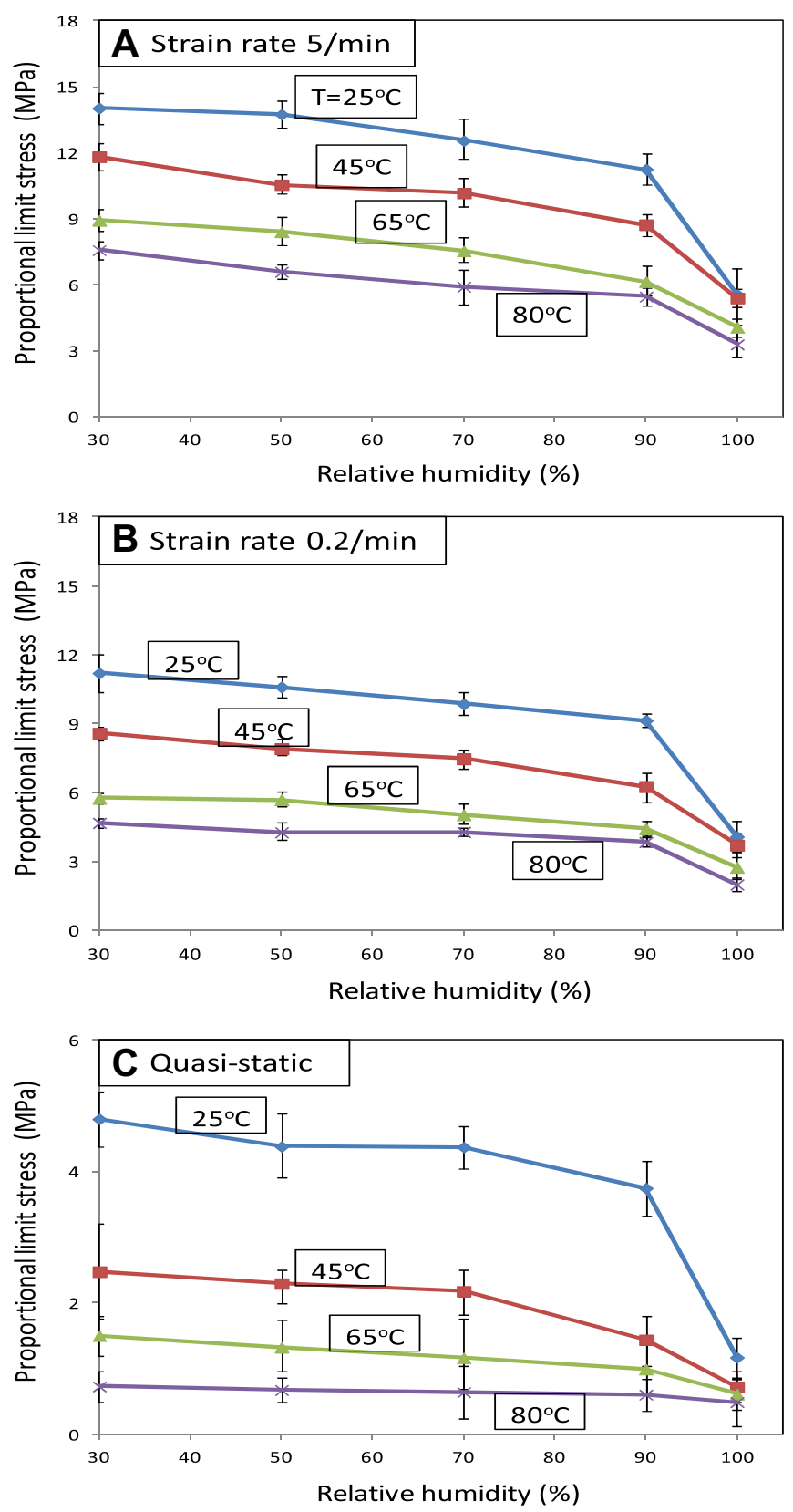

Fig. 14. Proportional limit stress of Nafion ${ }^{\circledR} 211$ membranes as a function of relative humidity at various temperatures with a strain rate of (a) $5 \mathrm{~min}^{-1} \mathrm{~min}$; (b) $0.2 \mathrm{~min}$ ${ }^{-1} \mathrm{~min}$; and (c) quasi-static. graphically as the stress at the intersection of the tangents to the initial linear portion of the curve and the initial strain hardening response (Fig. 10) [13]. In addition, the secondary modulus is discussed in our companion paper [19].

Young's modulus and proportional limit stress are determined from each true stress-true strain curve and the average values for samples at each strain rate/temperature/humidity combination are plotted in Figs. 11-14. Conditions plotted at relative humidity of $100 \%$ correspond to the liquid water tests. The results show that Young's modulus increases with increasing strain rate (Fig. 11), and decreases with increasing temperature or humidity (Fig. 12) ${ }^{4}$. Similarly, the proportional limit stress also increases with increasing strain rate (Fig. 13) while decreasing with increasing temperature or humidity (Fig. 14). Moreover, a significant decrease in Young's modulus and proportional limit stress is observed when the humidity changes from $90 \% \mathrm{RH}$ in air to the liquid water condition (Figs. 12 and 14). We have observed a similar phenomenon while studying the time-independent behavior of the Nafion ${ }^{\circledR}$ 112 membrane [22]. As we did in that study, we attribute this abrupt change in properties to a significant increase in water absorption when the membrane is taken from fully saturated humid air to a liquid water environment [23-25].

\section{Concluding remarks}

The time-dependent hygro-thermal mechanical behavior of a PFSA membrane (Nafion ${ }^{\circledR} 211$ membrane) was investigated in this study. Two temperature/humidity cycles were used to investigate the swelling behavior of Nafion ${ }^{\circledR} 211$ membranes as a function of temperature and humidity. We found that the Nafion ${ }^{\circledR} 211$ membrane swells more with increasing temperature and humidity, and that the history of the hygro-thermal loading appears to have no effect on the steady state swelling behavior of the membrane. These measurements, along with an assumption of swelling isotropy, are used to calculate the true stress and true strain of the membranes in the tensile and relaxation tests reported in this study.

Tensile tests and relaxation tests were conducted at selected strain rates for a range of temperatures and humidities. Young's modulus and the proportional limit stress as functions of strain rate, temperature and humidity were determined. The results show that Young's modulus and the proportional limit stress both increase as the strain rate increases, temperature decreases or humidity decreases. The results also show that the mechanical response of Nafion ${ }^{\circledR} 211$ membranes is more sensitive to typical changes in strain rate and temperature than to typical changes in humidity.

These results indicate that strain rate, temperature and humidity have significant effects on the mechanical behavior of Nafion ${ }^{\circledR} 211$ membranes. In a real fuel cell operation, the membrane experiences time varying strains, temperature and humidity. Therefore, it is important to incorporate these effects in mechanical simulations of the membrane used to predict stresses and ultimately to understand failure mechanisms.

\section{Acknowledgments}

This research has been supported by W.L. Gore \& Associates under a grant (DE-FC36-086018052) from the United States Department of Energy.

\footnotetext{
${ }^{4}$ Young's modulus of the membrane at $80^{\circ} \mathrm{C}$ appears as being nearly independent of RH due to the scale resolution. Actually, Young's modulus also decreases as
} the humidity increases at $80^{\circ} \mathrm{C}$ 


\section{References}

[1] W. Liu, K. Ruth, G. Rusch, Journal of New Materials for Electrochemical Systems 4 (2001) 227-231.

[2] S. Cleghorn, J. Kolde, W. Liu, in: V. Wolf, L. Arnold, G. Hubert (Eds.), Handbook of Fuel Cells - Fundamentals, Technology and Applications, John Wiley \& Sons, Ltd, 2003.

[3] E. Endoh, S. Terazono, H. Widjaja, Y. Takimoto, Electrochemical and Solid State Letters 7 (2004) A209-A211.

[4] M. Crum, W. Liu, ECS Transactions 3 (2006) 541-550.

[5] S. Kundu, M.W. Fowler, L.C. Simon, S. Grot, Journal of Power Sources 157 (2006) 650-656.

[6] V.A. Sethuraman, J.W. Weidner, A.T. Haug, L.V. Protsailo, Journal of the Electrochemical Society 155 (2008) B119-B124.

[7] A.Z. Webber, J. Newman, AIChE Journal 50 (2004) 3215-3226.

[8] Y.-H. Lai, C.S. Gittleman, C.K. Mittelsteadt, D.A. Dillard, Proceedings of the 3rd International Conference on Fuel Cell Science, Engineering, and Technology, Ypsilanti, MI, United States, 2005, pp. 161-167.

[9] M.F. Mathias, R. Makharia, H.A. Gasteiger, J.J. Conley, T.J. Fuller, C.J. Gittleman, S.S. Kocha, D.P. Miller, C.K. Mittelsteadt, T. Xie, S.G. Yan, P.T. Yu, Electrochemical Society Interface 14 (2005) 24-35.

[10] A. Kusoglu, A.M. Karlsson, M.H. Santare, S. Cleghorn, W.B. Johnson, Journal of Power Sources 161 (2006) 987-996.

[11] Y. Tang, M.H. Santare, A.M. Karlsson, S. Cleghorn, W.B. Johnson, Journal of Fuel Cell Science and Technology 3 (2006) 119-124.
[12] Z. Lu, C. Kim, A.M. Karlsson, J.C. Cross, M.H. Santare, Journal of Power Sources 196 (2011) 4646-4654

[13] Y. Tang, A.M. Karlsson, M.H. Santare, M. Gilert, S. Cleghorn, W.B. Johnson, Materials Science and Engineering A 425 (2006) 297-304

[14] M.N. Silberstein, P.V. Pillai, M.C. Boyce, Polymer 52 (2011) 529-539.

[15] M.N. Silberstein, M.C. Boyce, Journal of Power Sources 195 (2010) 5692-5706.

[16] R. Solasi, Y. Zou, X. Huang, K. Reifsnider, Mechanics of Time Dependent Materials 12 (2008) 15-30.

[17] Y.H. Lai, C.K. Mittelsteadt, C.S. Gittleman, D.A. Dillard, Journal of Fuel Cell Science and Technology 6 (2009) 021002-1-021002-13.

[18] A. Kusoglu, A.M. Karlsson, M.H. Santare, S. Cleghorn, W.B. Johnson, Journal of Power Sources 170 (2007) 345-358

[19] N.S. Khattra, A.M. Karlsson, M.H. Santare, P. Walsh, F.C. Busby, Journal of Power Sources 214 (2012) 365-376.

[20] Y. Tang, A. Kusoglu, A.M. Karlsson, M.H. Santare, S. Cleghorn, W.B. Johnson, Journal of Power Sources 175 (2008) 817-825.

[21] P. Schroeder, Zeitschrift Fur Physikalische Chemie 45 (1903) 75

[22] A. Kusoglu, Y. Tang, M. Lugo, A.M. Karlsson, M.H. Santare, S. Cleghorn, W.B. Johnson, Journal of Power Sources 195 (2010) 483-492.

[23] J.T. Hinatsu, M. Mizuhata, H. Takenaka, Journal of the Electrochemical Society 141 (1994) 1493-1498.

[24] T.A. Zawodzinski, C. Derouin, S. Radzinski, R.J. Sherman, V.T. Smith, T.E. Springer, S. Gottesfeld, Journal of the Electrochemical Society 140 (1993) 1041-1047.

[25] D.R. Morris, X.D. Sun, Journal of Applied Polymer Science 50 (1993) $1445-1452$

Post-print standardized by MSL Academic Endeavors, the imprint of the Michael Schwartz Library at Cleveland State University, 2014 